\title{
PENGARUH KUALITAS WEBSITE TERHADAP KEPERCAYAAN PELANGGAN DALAM MENENTUKAN KEPUTUSAN BERTRANSAKSI PADA E-COMMERCE (Studi Pada Pelanggan E-Commerce di Indonesia)
}

\author{
The Impact of Website Quality on Consumers Trust in Determining the Transaction Decisions \\ on e-Commerce: The Indonesian Case
}

\author{
Rian Piarna ${ }^{1}$ \\ ${ }^{1}$ Manajemen, Fakultas Ekonomi dan Bisnis, Universitas Teknologi Sumbawa \\ *) e-mail: piarnarian@gmail.com
}

Tanggal Diterima: 08 September 2016

\begin{abstract}
The purposes of this research are (1) to explain the influence of website quality to transaction trust on e-commerce's; (2) to explain the effect of website quality on customer's decision in e-commerce transaction (3) to explain the influence of trust to transaction on e-commerce. There were 150 samples of Indonesian e-commerce customers in this research. Main instrument on data collection is questionnaire which is distributed through social media (Facebook, Twitter, and Blogs) and measured by Likert Scale. Data analysis was conducted using Structural Equation Model (SEM). The result of this research showed that website's quality has significant influences on e-commerce customers trust. Meanwhile, the website quality has no direct effect on transaction decissions.
\end{abstract}

Keywords: e-commerce, website quality, information source, trust, decision

\section{ABSTRAK}

Penelitian ini bertujuan untuk: (1) menganalisis pengaruh kualitas website terhadap kepercayaan untuk bertransaksi pada ecommerce; (2) menganalisis pengaruh kualitas website terhadap keputusan konsumen dalam bertransaksi pada e-commerce; (3) mengetahui pengaruh kepercayaan terhadap transaksi pada e-commerce. Sampel penelitian sebanyak 150 pelanggan e-commerce di Indonesia. Pengumpulan data menggunakan kuesioner online melalui social media (Facebook, Twitter dan Blogs) dengan diukur Skala Likert serta dianalisis dengan Structural Equation Model (SEM). Hasilnya menunjukkan kualitas website memiliki pengaruh signifikan terhadap kepercayaan pelanggan e-commerce namun tidak berpengaruh langsung terhadap keputusan bertransaksi.

Kata Kunci: e-commerce, kualitas website, sumber informasi, kepercayaan, keputusan bertransaksi

\section{Pendahuluan}

Toffler (1980) memprediksikan pada gelombang ketiga peradaban manusia ditandai dengan derasnya arus komunikasi akibat revolusi teknologi informasi di berbagai aspek kehidupan (Suwirta, 2012). Salah satu media informasi yang berkembang dengan cepat saat ini adalah internet. Perkembangan internet yang semakin pesat berdampak pada kegiatan bisnis yaitu dengan adanya bisnis online. Bisnis online pada mulanya hanya melakukan penjualan buku, majalah, kaset dan piringan (LaQuey, 1997).

Kegiatan bisnis online terus berkembang seiring dengan perkembangan bisnis dan teknologi informasi sebagai contoh pada 1994 Pizza Hut di Amerika Serikat menawarkan pemesanan online di situs webnya dan pada 1995 Amazon.com mulai menjual buku secara online. Pada tahun 2015 penjualan online di dunia diprediksi menembus US\$ 119 miliar via telepon seluler dan US\$ 1,4 triliun via komputer (Tempo.co, 2012). Bisnis online merupakan kegiatan electronic commerce (e- commerce) dimana aktifitas menjual dan membeli produk atau jasa melalui internet. (Hausman dan Siekpe, 2009)

Lembaga riset di AS, e-Marketer melaporkan penjualan ritel global melalui internet melampaui US\$ 1 triliun sepanjang 2012. Sementara itu penjualan konsumen e-commerce tumbuh $21,1 \%$ menjadi lebih dari US\$ 1 triliun dan diperkirakan akan tumbuh 18,3\% pada 2013. Hasil survei MasterCard menunjukkan aktivitas belanja online antara negara-negara maju dan negara-negara berkembang di kawasan Asia Pasifik tidak jauh berbeda dengan meningkatnya antusiasme melakukan belanja secara mobile di negara-negara Asia Tenggara termasuk Indonesia (Zoel, 2012).

Indonesia pada Juni 2012 menduduki peringkat ke empat untuk jumlah pengguna internet di kawasan Asia. Jumlah pengguna internet di Indonesia sebanyak 55 juta dan 51 juta diantaranya memiliki akun facebook (www.internetworldstats.com). Menurut Asosiasi Penyelenggara Jasa Internet Indonesia, pengguna internet di Indonesia pada tahun 2012 mencapai 63 juta orang dan diprediksi pada tahun 2015 mengalami 
peningkatan drastis menjadi 139 juta pengguna (www.apjii.or.id).

Jumlah pengguna internet di Indonesia yang terus meningkat didorong popularitas facebook menjadikan masyarakat tidak lagi menganggap internet hanya digunakan untuk kegiatan intelektual, namun lebih dari itu internet digunakan untuk membuat jejaring sosial. Kondisi tersebut memberikan peluang besar e-commerce untuk semakin tumbuh berkembang di Indonesia (Sulianta, 2012). Tingkat kesadaran masyarakat Indonesia terhadap e-commerce turut menumbuhkan penjualan online melalui media sosial (Rosalina, 2013). Survei Nielsen bertajuk "Global Consumer Confidence and Spending Intentions" memprediksikan daya beli konsumen Indonesia tetap kuat di 2013. Hal tersebut dikarenakan tingginya populasi kelas menengah sehingga pertumbuhan bisnis akan sangat besar (Silalahi, 2013). Perkembangan e-commerce di Indonesia ditandai dengan tumbuhnya jumlah situs jual beli yang cukup drastis. Istilah startup dipakai oleh kaum muda Indonesia untuk memulai bisnis di internet (Zoel, 2012).

Kegiatan transaksi jual beli di internet dimulai dengan kegiatan forum jual beli diantaranya adalah www.kaskus.co.id, www.tokobagus.com, www.berniaga.com, www.bukalapak.com serta forum jual beli lainnya. Setelah forum jual beli yang semakin marak, konsep belanja di mall dengan media internet kemudian tumbuh seperti www.rakuten.co.id, www. lazada.co.id, www.zalora.co.id, www.blibli.com dan masih banyak toko online lainnya.

Kondisi kegiatan transaksi pembeliaan secara online di Indonesia berdasarkan hasil studi yang dipaparkan oleh Spire menunjukkan bahwa $90 \%$ orang mencari referensi/informasi melalui rekomendasi dari orang yang mereka kenal sebelum melakukan transaksi online. Forum Jual Beli Kaskus merupakan portal paling favorit sebagai media transaksi online di Indonesia,. Fakta lain menunjukkan bahwa $73 \%$ orang mengakses Kaskus karena memperoleh rekomendasi dari teman (Zoel, 2012).

Salah satu faktor yang mendorong konsumen melakukan kegiatan e-commerce adalah kualitas website. Website suatu perusahaan harus mempresentasikan kehadiran perusahaan tersebut di mata pelanggan secara virtual sehingga konsumen menjadi percaya dan melakukan transaksi secara online melalui website perusahaan (Sarwono dan Prihartono, 2012). Beberapa penelitian mengenai pengaruh kualitas website terhadap kepercayaan konsumen untuk melakukan transaksi pada $e$ commerce telah banyak dilakukan diantaranya Al-Dwairi (2013) meneliti sistem keamanan, privasi, desain dan isi sebuah website; O'Cass dan Carlson (2012) tentang inovasi fitur website; Rolland dan Freeman (2010) tentang kemudahan akses, informasi, pelayanan, keamanan dan kepercayaan; Al-maghrabi dan Dennis (2010) tentang penampilan yang atraktif dari layout, navigasi dan konten informatif; dan Shin et al. (2013) tentang kemudahan belanja, desain website, ketersediaan informasi, keamanan transaksi, sistem pembayaran dan pelayanan.

Dalam beberapa penelitian dimensi kualitas website juga berpengaruh secara langsung terhadap niat bertransaksi konsumen pada e-commerce seperti Chen (2013) menemukan kualitas sistem, kualitas informasi dan kualitas pelayanan berpengaruh signifikan terhadap niat bertransaksi pada mobile shopping (m-shopping). Hsiu dan Shih (2013) dan Yu et al. (2009) hanya menemukan kualitas pelayanan yang berpengaruh secara signifikan. Sam dan Tahir (2009) meneliti kualitas website seperti kegunaan, desain, kualitas informasi, kepercayaan, persepsi resiko dan empati mempunyai pengaruh signifikan terhadap niat konsumen dalam pembelian tiket pesawat.

Dari beberapa penelitian tersebut tiga faktor kualitas website yang sering diteliti adalah kualitas sistem (Al Dwairi, 2013; Chen, 2013; Hsiu dan Shih, 2013; Ha dan Stoel, 2009; Maditinos et al., 2009; Rolland dan Freeman, 2010; McKnight et al., 2002; Shankar et al., 2002; Shin et al., 2013; Corbitt et al., 2002; Al Maghrabi dan Dennis, 2010). Kualitas informasi (Chen, 2013; Hsiu dan Shih, 2013; Webb dan Webb, 2001; Barnes dan Vidgen, 2003; Chao et al., 2005; Corbitt et al., 2003; Shankar et al., 2002; McKnight et al., 2002; Bai et al., 2008 dan Rolland dan Freeman, 2009), Kualitas pelayanan (Chen, 2013; Hsiu dan Shih, 2013; Webb dan Webb, 2001; Cao et al., 2005; Barnes dan Vidgen, 2003; Kassim dan Abdullah, 2010; Kim et al., 2005; McKnight et al., 2002; Rolland dan Freeman, 2009; Cox dan Dale, 2002; Barnes dan Vidgen, 2003; Ha dan Stoel, 2009 serta Hwang dan Kim , 2007). Penelitian dari ketiga faktor kualitas website tersebut masih terjadi perbedaan hasil, oleh karena itu perlu dilakukan penelitian lanjutan yang mendalam mengenai pengaruh ketiga faktor kualitas website terhadap kepercayaan pelanggan dalam melakukan transaksi pada $e$ commerce.

Kredibilitas dalam setiap transaksi juga merupakan faktor yang mempengaruhi niat konsumen dalam transaksi secara online mengingat transaksi online rentan terhadap hal-hal negatif. Berdasarkan laporan Norton bertajuk "Human Impact", sebanyak $86 \%$ pengguna internet pernah menjadi korban kejahatan cyber. Menurut MasterCard , 51\% responden di Indonesia yang selama tiga bulan terakhir tidak melakukan transaksi belanja secara online mengatakan mereka mengkhawatirkan aspek keamanan saat bertransaksi online (Zoel, 2012). Sebagian besar pelanggan masih ragu untuk melakukan pembelian melalui web milik penjual yang belum dikenalnya (Laudon dan Laudon, 2005). Dengan demikian kepercayaan konsumen terhadap kegiatan transaksi online memiliki peranan yang sangat penting.

McKnight et al. (2002) meneliti tentang model kepercayaan konsumen terhadap sebuah website dalam melakukan transaksi online. Shankar et al. (2002) meneliti tentang kepercayaan konsumen dalam melakukan transaksi online yang dipengaruhi oleh karakteristik website, karakter pengguna maupun karakter eksternal. Yu dan Barnes (2007) juga meneliti tentang dimensi kepercayaan konsumen terhadap pembelian online. Dari datadata yang disajikan, ada korelasi antara sumber informasi, kualitas website, kepercayaan dan keputusan bertransaksi. Sehingga, perlu dilakukan penelitan lebih dalam tentang pengaruh sumber informasi dan kualitas website terhadap kepercayaan dan keputusan bertransaksi berbelanja online.

Dari beberapa penelitian tersebut faktor-faktor kualitas website seperti kualitas sistem, kualitas informasi dan kualitas pelayanan memiliki pengaruh terhadap tingkat kepercayaan dan keputusan bertransaksi konsumen e-commerce sehingga hipotesis yang diajukan dalam penelitian ini adalah;

Hipotesis 1: Kualitas Website mempunyai pengaruh terhadap tingkat kepercayaan (trust) pelanggan e-commerce.

Hipotesis 2: Kualitas Website mempunyai pengaruh terhadap keputusan bertransaksi melalui e-commerce.

Hasil penelitian yang dilakukan Al Dwairi (2013) menemukan bahwa keamanan, privasi, desain dan isi website e-commerce 
memiliki pengaruh terhadap kepercayaan konsumen dalam melakukan transaksi online. McKnight et al. (2002) meneliti tentang model kepercayaan konsumen terhadap sebuah website dalam melakukan transaksi online. Shankar et al. (2002) meneliti tentang kepercayaan konsumen melakukan transaksi online yang dipengaruhi karakteristik website, karakter pengguna maupun karakter eksternal. Yu dan Barnes (2007) juga meneliti tentang dimensi kepercayaan konsumen terhadap pembelian online.

Kepercayaan berdampak positif pada niat pembelian online karena konsumen percaya pada kebaikan hati dan integritas peritel online (Huei dan Gee, 2006). Hubungan antara kepercayaan dan niat membeli online telah diteliti hanya sebatas pada saat mengunjungi sebuah website (McKnight et al.,2002) dan sesudahnya (Gefen, 2000 dan Jae et al.,2004). Belum banyak penelitian yang membahas sebelum mengenali sebuah website e-commerce. Dari beberapa penelitian tersebut hipotesis yang diajukan dalam penelitian ini adalah.

Hipotesis 3: Kepercayaan (trust) mempunyai pengaruh terhadap keputusan bertransaksi melalui e-commerce.

Berdasarkan keterangan diatas, kerangka hipotesis dalam penelitian ini dapat dilihat pada gambar berikut:

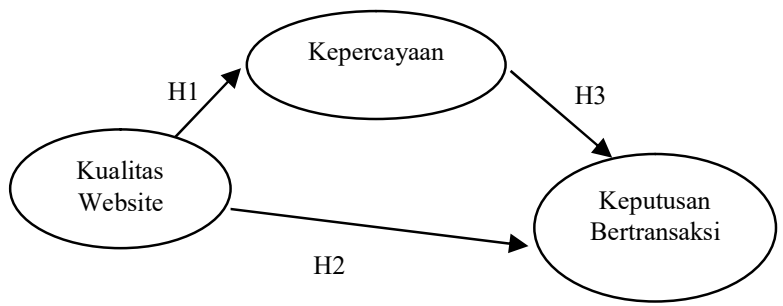

Gambar 1. Kerangka Hipotesis Penelitian

\section{Metode Penelitian}

Metode yang digunakan pada penelitian ini adalah metode survei. Menurut Kerlinger yang dikutip oleh Sugiyono (2008) menyatakan penelitian survei merupakan penelitian yang dilakukan pada populasi besar maupun kecil, tetapi data yang dipelajari adalah data dari sampel yang diambil dari populasi tersebut, sehingga ditemukan kejadian-kejadian relatif, distribusi, dan hubungan-hubungan antar variabel sosiologis maupun psikologis. Adapun alat analisis yang digunakan adalah analisis Structural Equation Model (SEM). Analisis SEM memungkinkan penilaian hubungan secara menyeluruh dan menyediakan analisis eksploratori dan analisis konfirmatori (Hair et al., 1998).

Populasi yang dipilih adalah pelanggan e-commerce di Indonesia yang sudah melakukan transaksi pembelian online melalui website. Mengingat jumlah populasi relatif besar dan tidak memungkinkan untuk diteliti secara keseluruhan, maka dilakukan teknik sampling. Teknik judgement sampling digunakan dalam penelitian ini karena pemilihan sampel didasarkan pada penilaian terhadap beberapa karaktersitik anggota sampel yang disesuaikan dengan maksud penelitian. Karakteristik yang digunakan unutuk memilih sampel pada penelitian ini adalah:

1. Pengguna internet yang mengenalkegiatan belanja online melalui web e- commerce.
2. Pengguna internet yang pernah melakukan pembelian sebuah produk melalui website e- commerce minimal satu kali.

Penentuan jumlah sampel disesuaikan dengan kriteria ideal besaran sampel untuk analisis pemodelan SEM yaitu 100-200 dan minimum absolut 50, atau besaran sampel minimum adalah 5-10 x variabel manifers atau indikator dari keseluruhan variabel laten. Mengacu pada pendekatan tersebut jumlah sampel yang dijadikan sebagai responden ditetapkan minimal sampel adalah sebesar 12 indikator X $10=120$ orang. Pengambilan sampel dilakukan dari bulan Juli - Agustus 2013 dan sampel yang berhasil dikumpulkan sebanyak 170 sampel dan hanya 150 sampel yang memenuhi kriteria. Karakteristik sampel disajikan pada Tabel 1 .

Tabel 1. Karakteristik Demografi Responden

\begin{tabular}{|c|c|c|}
\hline & Kategori & $(\%)$ \\
\hline \multirow{2}{*}{ Jenis kelamin } & Pria & 42 \\
\hline & Wanita & 58 \\
\hline \multirow{5}{*}{ Usia } & $\leq 18$ & 6 \\
\hline & $18-25$ & 57 \\
\hline & $26-35$ & 25 \\
\hline & $36-45$ & 11 \\
\hline & $\geq 46$ & 0 \\
\hline Asal & Indonesia Barat & 81 \\
\hline \multirow[t]{2}{*}{ Tinggal } & Indonesia Tengah & 10 \\
\hline & Indonesia Timur & 9 \\
\hline \multirow{5}{*}{ Pendidikan } & $\leq$ SLTA & 14 \\
\hline & Diploma 3 & 13 \\
\hline & Strata 1 & 63 \\
\hline & Strata 2 & 9 \\
\hline & Strata 3 & 1 \\
\hline \multirow{5}{*}{ Pekerjaan } & Pelajar-Mahasiswa & 28 \\
\hline & Dosen/Guru & 9 \\
\hline & Pegawai Negeri Sipil & 9 \\
\hline & Pegawai Swasta & 31 \\
\hline & Lainnya & 24 \\
\hline \multirow{4}{*}{ Pendapatan } & $<$ Rp. 1 Juta & 27 \\
\hline & Rp. 1 Juta $-2,5$ Juta & 33 \\
\hline & Rp. 2,5 Juta -5 Juta & 29 \\
\hline & $>$ Rp. 5 Juta & 12 \\
\hline \multirow{5}{*}{$\begin{array}{l}\text { Lokasi } \\
\text { Mengakses }\end{array}$} & Rumah & 62 \\
\hline & Kantor & 29 \\
\hline & Kampus & 5 \\
\hline & Warnet & 2 \\
\hline & Lainnya & 2 \\
\hline
\end{tabular}




\begin{tabular}{|c|c|c|}
\hline \multirow{6}{*}{$\begin{array}{l}\text { Sumber } \\
\text { informasi }\end{array}$} & Mesin Pencari & 68 \\
\hline & Keluarga & 1 \\
\hline & Teman & 11 \\
\hline & Iklan & 14 \\
\hline & Blogger & 4 \\
\hline & Lainnya & 2 \\
\hline \multirow{2}{*}{$\begin{array}{l}\text { Media } \\
\text { Mengakses }\end{array}$} & Komputer & 85 \\
\hline & Handphone & 15 \\
\hline \multirow{5}{*}{$\begin{array}{l}\text { Alasan } \\
\text { Penggunaan } \\
\text { Internet }\end{array}$} & $\begin{array}{l}\text { Dapat memilih produk } \\
\text { yang sesuai }\end{array}$ & 23 \\
\hline & Harga lebih murah & 5 \\
\hline & Lebih mudah dan cepat & 39 \\
\hline & $\begin{array}{l}\text { Akses informasi lebih } \\
\text { banyak }\end{array}$ & 27 \\
\hline & Lainnya & 6 \\
\hline \multirow{10}{*}{$\begin{array}{l}\text { Produk Yang } \\
\text { Sering Dibeli }\end{array}$} & Peralatan Elektronik & 15 \\
\hline & Peralatan Komputer & 7 \\
\hline & Peralatan Otomotif & 1 \\
\hline & Buku & 22 \\
\hline & $\mathrm{CD}$ & 1 \\
\hline & Baju & 33 \\
\hline & Tiket & 5 \\
\hline & Makanan & 1 \\
\hline & Souvenir & 2 \\
\hline & Lainnya & 13 \\
\hline
\end{tabular}

\section{Pengukuran}

Dalam penelitian indikator-indikator variabel kualitas website diantaranya kualitas informasi, kualitas sistem dan kualitas pelayanan. Indikator-indikator tersebut mencerminkan kelengkapan, akurasi informasi, sistem keamanan dan privasi, pelayanan yang responsif dan reliabiliti. Indikator tersebut diadopsi dari penelitian Ahn et al. (2004); Gee et al. (2012); Barnes dan Vidgen (2003); Cao et al. (2005); Al-Dwairi (2013); Yu dan Barnes (2007); Rolland dan Freeman (2010); Maditinos et al. (2009) dan Yu et al. (2009).

Variabel kepercayaan indikator-indikatornya adalah kebaikan, integritas dan kompetensi. Indikator-indikator tersebut mencerminkan kemauan, itikad baik, ketepatan, kejujuran, kemampuan dan pengetahuan. Indikator tersebut diadopsi dari penelitian McKnight et al. (2002); Al-maghrabi et al.(2010); Gee et al. (2012); Huei dan Gee (2006) dan Rofiq (2007). Variabel kepercayaan indikatornya adalah kebaikan, integritas dan kompetensi. Indikator-indikator tersebut mencerminkan kemauan, itikad baik, ketepatan, kejujuran, kemampuan dan pengetahuan. Indikator tersebut diadopsi dari penelitian McKnight et al. (2002); Al-maghrabi et al.(2010); Gee et al. (2012); Huei dan Gee (2006) dan Rofiq (2007).
Sedangkan indikator-indikator variabel keputusan bertransaksi adalah partisipasi, rekomendasi dan keberlanjutan. Indikatorindikator tersebut mencerminkan rasa suka, rekomendasi dan penambahan transaksi. Indikator tersebut diadopsi dari penelitian Jae et al. (2004); Kim dan Kim (2005); Rofiq (2007); Yu dan Barnes, 2007; Weng dan Ding (2012) dan Al-maghrabi et al. (2010).

Masing-masing item dalam penelitian ini diukur menggunakan Skala Likert dengan nilai 1 (sangat setuju) hingga 7 (sangat tidak setuju). Sebelum disebarkan, kuesioner terlebih dahulu dilakukan penelitian pendahuluan kepada 35 responden dan dari hasil yang didapatkan kuesioner valid dan reliabel sehingga penelitian bisa dilanjutkan.

\section{Hasil Penelitian}

\section{Pengujian Asumsi dalam SEM Uji Asumsi Normalitas}

Kriteria pengujian distribusi normal apabila nilai critical ratio multivariat (CR-multivariat) berada diantara nilai kritis $\mathrm{Z}$ sebesar $\pm 2,58$ maka data dinyatakan berdistribusi normal begitu juga sebaliknya. Hasil pengujian menunjukkan bahwa nilai $C R$ multivariat sebesar 11,639. Nilai CR-multivariat tersebut memiliki nilai yang berada di luar nilai kritis $Z$ sebesar $\pm 2,58$. Dengan demikian data yang digunakan pada penelitian ini tidak berdistribusi normal. Walaupun begitu secara teori dalil limit pusat (central limit theorem) apabila besarnya sampel lebih dari sama dengan 120 maka data dianggap berdistribusi normal meskipun pengujian yang dihasilkan tidak berdistribusi normal. Dengan demikian, dikarenakan data yang digunakan dalam penelitian ini sebesar 150 maka dapat dinyatakan asumsi normalitas telah terpenuhi.

\section{Uji Asumsi Outlier}

Pengujian outlier dilakukan melalui kriteria jarak mahalanobis. Jarak mahalanobis dievaluasi menggunakan $\chi^{2}$ pada derajat bebas sebesar jumlah variabel yang digunakan dalam penelitian ini. Kriteria pengujian apabila terdapat jarak mahalanobis lebih

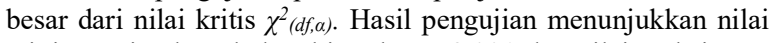
minimum jarak mahalanobis sebesar 8,001 dan nilai maksimum jarak mahalanobis sebesar 40,680. Nilai maksimum jarak mahalanobis menunjukkan nilai yang lebih kecil dari nilai kritis. Dengan demikian data yang digunakan dalam penelitian ini tidak mengandung outlier.

\section{Uji Asumsi Linieritas}

Pengujian asumsi linieritas dimaksudkan untuk mengetahui apakan terjadi hubungan linier antara variabel eksogen terhadap variabel endogen. Pengujian Asumsi Linieritas dilakukan menggunakan Curve Estimation menggunakan software SPSS.

Hasil pengujian asumsi linieritas pada Tabel 2 berikut :

Tabel 2. Hasil Uji Asumsi Linieritas

\begin{tabular}{lcc}
\hline \multicolumn{1}{c}{ Variabel } & F statistik & Sig. \\
\hline $\begin{array}{l}\text { Kualitas Website } \rightarrow \\
\text { Kepercayaan }\end{array}$ & 154.986 & 0.000 \\
$\begin{array}{l}\text { Kualitas Website } \rightarrow \\
\text { Keputusan }\end{array}$ & 85.991 & 0.000 \\
Kepercayaan $\rightarrow$ Keputusan & 140.639 & 0.000 \\
\hline
\end{tabular}


Kriteria pengujian menyebutkan bahwa apabila nilai probabilitas dari statistik uji $\mathrm{F}<$ level of significant $(\alpha=5 \%)$ maka dinyatakan terdapat hubungan linier antara variabel eksogen terhadap variabel endogen. Berdasarkan hasil pengujian, dapat diketahui bahwa hubungan antara variabel adalah linier karena probabilitas < alpha $(5 \%)$.

\section{Uji Kecocokan Keseluruhan Model}

Uji kecocokan keseluruhan model berkaitan dengan analisis terhadap Goodness of fit (GOF) statistik yang dihasilkan oleh program LISREL 8.80 yang terdiri dari tujuh kelompk yang terdiri dari 15 ukuran. Hasil pengujian menunjukkan 4 ukuran GOF kurang baik, 9 ukuran GOF menunjukkan kecocokan yang baik (good fit) serta 2 ukuran GOF menunjukkan kecocokan marginal fit sehingga kecocokan keseluruhan model pada penelitian ini dinyatakan Good Fit (baik).

\section{Pengujian Signifikansi}

Pengujian signifikansi digunakan untuk menguji hipotesis mengenai kausalitas yang dikembangkan dalam model yaitu pengaruh variabel eksogen terhadap variabel endogen yang telah dikembangkan. Hasil pengujian signifikansi dapat diketahui pada Tabel 3 berikut.

Tabel 3 Evaluasi Koefisien Model Struktural

\begin{tabular}{clcc}
\hline H & \multicolumn{1}{c}{ Path } & Estimasi & Nilai-t \\
\hline 1 & $\begin{array}{l}\text { Kualitas Website } \rightarrow \\
\text { Kepercayaan }\end{array}$ & 0,94 & 8,35 \\
2 & $\begin{array}{l}\text { Kualitas } \text { Website } \rightarrow \\
\text { Kepputusan }\end{array}$ & 0,14 & 0,40 \\
3 & $\begin{array}{l}\text { Kepercayaan } \rightarrow \\
\text { Keputusan }\end{array}$ & 0,68 & 2,12 \\
\hline
\end{tabular}

Pada hasil pengujian H1 dapat diketahui bahwa nilai t antara kualitas website terhadap keputusan tingkat kepercayaan (trust) pelanggan e-commerce adalah 8,35 . Hasil pengujian ini menunjukkan bahwa nilai t lebih besar dari nilai kritis 1,96. Hal ini berarti variabel kualitas website berpengaruh secara langsung terhadap tingkat kepercayaankonsumen dalam berbelanja melalui website e-commerce.

Pada hasil pengujian $\mathrm{H} 2$ dapat diketahui bahwa nilai t antara kualitas website terhadap keputusan bertransaksi melalui website e-commerce adalah 0,40 . Hasil pengujian ini menunjukkan bahwa nilai t lebih kecil dari nilai kritis 1,96 . Hal ini berarti variabel kualitas website secara langsung tidak berpengaruh terhadap keputusan bertransaksi melalui website e-commerce.

Pada hasil pengujian H3 dapat diketahui bahwa nilai $t$ antara kepercayaaan terhadap terhadap keputusan bertransaksi melalui e-commerce adalah 2,12. Hasil pengujian ini menunjukkan bahwa nilai t lebih besar dari nilai kritis 1,96 . Hal ini berarti variabel kualitas kepercayaan berpengaruh secara langsung terhadap keputusan bertransaksi melalui website e-commerce.

\section{Pembahasan}

Kualitas website berpengaruh terhadap kepercayaan berbelanja melalui website e-commerce. Hal ini sejalan dengan penelitianpenelitian sebelumnya seperti Barnes dan Vidgen (2003), Ahn et al. (2004), Cao et al. (2005), Yu dan Barnes (2007), Maditinos et al. (2009) dan Yu et al. (2009), Rolland dan Freeman (2010), Gee et al. (2012), dan Al-Dwairi (2013).
Kualitas website merupakan faktor terpenting bagi konsumen yang akan berbelanja secara online setelah memperhatikan kualitas informasi, sistem dan pelayanan yang disediakan. Hal ini berarti agar responden lebih mempercayai transaksi pembelian online melalui website e-commerce yang bersangkutan harus memiliki kualitas yang tinggi.

Kualitas website secara langsung tidak berpengaruh terhadap keputusan bertransaksi melalui website e-commerce. Penelitian ini berbeda hasilnya dengan penelitian-penelitian sebelumnya seperti pada Chen (2013); Hsiu dan Shih (2013); Sam dan Tahir (2009); Saputra et al. (2012) dan Yu et al. (2009) yang menyatakan ada pengaruh signifikan antara kualitas website dengan keputusan pembelian konsumen e-commerce. Hal ini dapat diartikan tinggi rendahnya kualitas website e-commerce maka tidak akan mengubah sikap responden untuk mengambil keputusan membeli produk atau berbelanja melalui website ecommerce. Akan tetapi, setelah mendapatkan mediasi dari variabel kepercayaan berbelanja melalui website e-commerce maka secara tidak langsung kualitas website e-commerce berpengaruh terhadap keputusan bertransaksi melalui website ecommerce.

Secara langsung kepercayaan berbelanja melalui website ecommerce berpengaruh terhadap keputusan bertransaksi melalui website e-commerce. Hasil ini sejalan dengan penelitianpenelitian yang dilakukan oleh Al Dwairi (2013); McKnight et al. (2002) ; Shankar et al. (2002); Barnes (2007); Huei dan Gee, (2006); Gefen, (2000) dan Jae et al.(2004). Hal ini menunjukkan bahwa kepercayaan konsumen terhadap transaksi e-commerce membuat konsumen menyukai kegiatan belanja online seperti pada penelitian Jae et al. (2004), Kim dan Kim (2005) dan Weng dan Ding (2012). Setelah konsumen menyukai kegiatan belanja online maka konsumen akan meningkatkan kegiatan belanja online (Yu dan Barnes, 2007) dan merekomendasi untuk belanja online kepada konsumen lain Al-maghrabi et al. (2010), Kim dan Kim (2005), Rofiq (2007).

\section{Kesimpulan}

Kualitas website berpengaruh terhadap kepercayaan berbelanja online melalui website e-commerce. Hasil penelitian ini sejalan dengan penelitian-penelitian sebelumnya seperti Shin et al. (2013); Al-Dwairi (2013); O'Cass dan Carlson (2011); Almaghrabi et al. (2010) dan Bai et al. (2007) yang menunjukkan bahwa kualitas informasi, kualitas sistem dan kualitas pelayanan pada website e-commerce mempengaruhi kepercayaan konsumen untuk belanja online.

Namun, kualitas website secara langsung tidak berpengaruh terhadap keputusan bertransaksi melalui website e-commerce. Kualitas website e-commerce tidak menjamin keputusan bertransaksi, konsumen terlebih dahulu harus mempercayai transaksi tersebut sehingga bisa mengubah sikap pelanggan untuk mengambil keputusan membeli produk atau berbelanja melalui website e-commerce.

Secara langsung kepercayaan berbelanja melalui website ecommerce berpengaruh terhadap keputusan bertransaksi melalui website e-commerce. Hal ini menunjukkan bahwa kepercayaan konsumen terhadap transaksi e-commerce membuat konsumen menyukai kegiatan belanja online.

\section{Saran}

Berdasarkan hasil penelitian kualitas informasi, sistem dan pelayanan berperan penting pada kualitas website dalam meningkatkan kepercayaan konsumen terhadap website e- 
commerce. Sehingga, hal yang perlu dilakukan oleh vendor website e-commerce adalah terus meningkatkan kualitas website yang bisa ditinjau dari segi kualitas informasi, kualitas sistem dan kualitas pelayanan. Kualitas website akan meningkatkan kepercayaan konsumen untuk berbelanja online.

\section{Daftar Pustaka}

Ahn T, Ryu S dan Han I. 2004. 'The impact of the online and offline features on the user acceptance of Internet shopping malls'. Electronic Commerce Research and Applications.

Al-Dwairi, Radwan M. 2013.'E-Commerce Web Sites Trust Factors: An Empirical Approach,' Contemporary Engineering Sciences, Vol. 6, no. 1, 1-7

Al-maghrabi T, Dennis C. dan Halliday S.V. 2010. 'Antecedents of continuance intentions towards e-shopping: the case of Saudi Arabia,' Journal of Enterprise Information Management. Vol. 24 No. 1, pp. 85-111

Bai B, Law R. dan Wen I.2007.'The impact of website quality on customer satisfaction and purchase intentions: Evidence from Chinese online visitors',International Journal of Hospitality Management. Vol 27, PP.391-402

Barnes S dan Vidgen R.2003.'Measuring Web site quality improvements: A case study of the forum on strategic management knowledge exchange'. Industrial Management + Data Systems. 103, 5/6, ProQuest pg. 297

Cao M, Zhang Q dan Seydel J.2005.'B2C e-commerce web site quality: an empirical examination'.Industrial Management + Data Systems.105, 5/6

Chen, Lisa Y.2013.'The Quality Of Mobile Shopping System and Its Impact on Purchase Intention dan Performance'.International Journal of Managing Information Technology (IJMIT) Vol.5, No.2

Chin, H,L, Judy Chuan, L,C dan Hsiu, C,S. 2012. 'The effects of blogger recommendations on customers'online shopping intentions' Internet Research. Vol. 23 No. 1, pp. 69-88

Corbitt B.J,Thanasankit $\mathrm{T}$ dan Yi H. 2003.'Trust and ecommerce: A study of consumer perceptions'. Electronic Commerce Research and Applications. Vol 2 Pp. 203-215

Cox J dan Dale B.G.2002.'Key quality factors in Web site design and use: An examination'.The International Journal of Quality \& Reliability Management. Vol 19, 6/7

Gee, B.W, Lee, J, Huei, K dan Jong Kim, 2012. 'The progression of online trust in the multi-channel retailer context and the role of product uncertainty'. Decision Support Systems . pp. 97-107

Ha, S dan Stoel, L. 2009.'Consumer e-shopping acceptance: Antecedents in a technology acceptance model'.Journal of Business Research. Vol 62 pp 565-571

Hair, JF, Anderson, RE, Tatham, RL \& Black, WC 1998, Multivariate Data Analysis, Edisi 5, Prentice Hall Inc, New Jersey.

Hausman, A. V dan Siekpe Sam J. 2009, 'The effect of web interface features on consumer online purchase intentions', Journal of Business Research, Vol 62 pp .5-13

http://internetworldstats.com/stats.htm Diakses 24 Maret 2013 http://www.apjii.or.id/v2/index.php/read/page/halamandata/9/statistik.html Diakses 24 Maret 2013

Huei H K dan Gee W.B.2006.'Trust transference in brick and click retailers: An investigation of the before-online-visit phase' Information \& Management. Vol 44 hh.175-187

Huei, Chen S. 2007.'How Advertising Affects: A Study of the Chinese E-market'.Asian Journal of Management and Humanity Sciences. Vol. 1, No. 4, pp. 539-557

Hwang, Y. dan Kim J. 2007. 'Customer self-service systems: The effects of perceived Web quality with service contents on enjoyment, anxiety, and e-trust,'Decision Support Systems.Vol 43 pp. 746-760

Jae I, Hee C.L dan Hae J.K.2004.'Factors Affecting Online Search Intention and Online Purchase Intention'.Seoul Journal of Business. Volume 10, Number 2

Kassim N dan Abdullah Nor A.2010.'The effect of perceived service quality dimensions on customer satisfaction, trust, and loyalty in e-commerce settings A cross cultural analysis'.Asia Pacific Journal of Marketing and Logistics. Vol. 22 No. 3, pp. 351-371

Kim Y.H dan Kim D.2005.'A Study of Online Transaction SelfEfficacy, Consumer Trust, and Uncertainty Reduction in Electronic Commerce '.Proceedings of the 38th Hawaii International Conference on System Sciences

Kim M, Jung H.K dan Lennon, J.2005'Online service attributes available on apparel retail web sites: an E-S-QUAL approach'. Managing Service Quality.16, 1; ABI/INFORM Completepg. 51

LaQuey, T. 1997.Internet Companion: A Beginner's Guide to Global Networking. Wospakrik, Hans J. (penerjemah). Sahabat Internet: Pedoman bagi pemula untuk memasuki jaringan global.Penerbit ITB. Bandung.

Laudon, K.C., dan Laudon, J.P., 2005. Management Information Systems:Managing the Digital Firm, Eight Edition. Philiphus, E. Sistem Informasi Manajemen. Mengelola Perusahaan Digital.Penerbit Andi.Yogyakarta.

Maditinos D, Sarigiannidis L dan Kesidou E. 2009. 'Consumer Characteristics and Their Effect On Accepting Online Shopping, In The Context Of Different Product Types'. Proceedings 5th HSSS Conference, Democritus University of Thrace, Xanthi, Greece, 24-27 June.

McKnight,D.H, Choudhury V dan Kacmar C.2002.'The impact of initial consumer trust on intentions to transact with a web site: a trust building model'.Journal of Strategic Information Systems. Vol 11 pp. 297-323

O'Cass, A. dan Carlson, J. 2011. 'An e-retailing assessment of perceived website-service innovativeness: Implications for website quality evaluations, trust, loyalty and word of mouth,' Australasian Marketing Journal. Vol 20. Pp 28-36

Rofiq, Ainur.2007. Pengaruh Dimensi Kepercayaan (Trust) Terhadap Partsipasi Pelanggan E-Commerce. Tesis.Program Pascasarjana Fakultas Ekonomi Universitas Brawijaya.

Rolland, S.dan Freeman I. 2010.'A new measure of e-service quality in France'. International Journal of Retail \& Distribution Management. Vol. 38 No. 7, pp. 497-517 
Rosalina. 2013. 'E-commerce Dorong Fungsi Media Sosial untuk Jualan'. 03 Juli, Diakses 06 Juli 2013. http://www.tempo.co/read/news/2013/07/03/072493322/ Ecommerce-Dorong-Fungsi-Media-Sosial-untuk-Jualan

Sam M dan Tahir H.2009.'Website Quality And Consumer Online Purchase Intention of Air Ticket'.International Journal of Basic \& Applied Sciences IJBAS Vol: 9 No: 10.

Saputra,Ruswiati S, Warokka A dan Naruephai N.2012.'The Key Drivers of Online Consumers' Intention to Purchase in an Online Auction: A Reference from Southeast Emerging Market'. Journal of Internet and e-Business Studies.Vol. 2012

Sarwono J dan Prihartono K.A.H. 2012. Perdagangan Online: Cara Bisnis di Internet. Penerbit PT Elex Media Komputindo. Jakarta.

Shankar V., Urban G.L dan Sultan F.2002.'Online trust: a stakeholder perspective, concepts, implications, and future directions'.Journal of Strategic Information Systems. Vol 11 pp. $325-344$

Shin, J, I, Chung, H, K, Oh, S, J dan Lee, W,C. 2013. 'The effect of site quality on repurchase intention in Internet shopping through mediating variables: The case of university students in South Korea,' International Journal of Information Management. Vol 33 pp. 453- 463

Silalahi, M, 2013, 'Tingkat Belanja Konsumen Indonesia Masih Tinggi', Diakses 20 Maret 2013 http://mix.co.id/research/2013-tingkat-belanja-konsumenindonesia-masih-tinggi/

Sugiyono 2008, Metode Penelitian Bisnis, Alfabeta, Bandung.

Sulianta, F.2012.Smart Online Marketer. Edisi Pertama. Penerbit Andi.Yogyakarta.

Suwirta A, 2012, 'Setelah Gelombang III: What's Next?', 15 Juni, Diakses 24 Maret 2013, http://aspensi.com/views/2012/06/15/1037/1270000-setelahgelombang-iii-what $\% \mathrm{E} 2 \% 80 \% 99 \mathrm{~s}$-next

Toffler, A 1980.The Thrid Wave.Bantham Book. USA

Webb, Harold W dan Webb, Linda A. 2009. 'SiteQual: an integrated measure of Web Site quality'. Journal of Enterprise Information Management. Vol 17,Pg. 430

Weng, M.L dan Ding, H.T. 2012. 'LimE-shopping: an Analysis of the Technology Acceptance Model'.Modern Applied Science.Vol. 6, No. 4.

Yu Chen, H dan Barnes S. 2007. 'Initial trust and online buyer behaviour,' Industrial Management \& Data Systems Vol. 107 No. 1, pp. 21-36

Yu, L, J, Ching, H,L, Lung, C,Y dan Ching, C, Y.2009.'Exploring the Influence of Online Consumers' Perception on Purchase Intention as Exemplified with an Online Bookstore'.Journal of Global Business Management.Vol. 5,No. 2.

Zoel,2012, 'Meningkatnya Pertumbuhan Belanja Online di Pasar Negara Berkembang', Diakses 20 Maret 2013, http://www.marketing.co.id/ blog/2012/06/ 18/meningkatnya-pertumbuhan- belanja-online-di-pasarnegara-berkembang/ 